\title{
New evidence of conspecificity between Hipparion primigenium melendezi Alberdi, 1974 from Los Valles de Fuentidueña (Segovia) and Hipparion concudense concudense Pirlot, 1956 from Concud (Teruel, Spain)
}

\author{
Nuevas evidencias de la coespecificidad entre Hipparion primigenium \\ melendezi Alberdi, 1974 de Los Valles de Fuentidueña (Segovia) e \\ Hipparion concudense concudense Pirlot, 1956 de Concud (Teruel, \\ España)
}

\author{
M.D. Pesquero ${ }^{1}$, M.T. Alberdi²
}

\begin{abstract}
This paper reports a morphological and biometric comparison of Hipparion primigenium melendezi from Los Valles de Fuentidueña (Segovia) and Hipparion concudense concudense from Concud (Teruel) to investigate their possible conspecificity. Comparisons with other Spanish (La Roma 2, Puente Minero, Milagros, Las Casiones and Venta del Moro) and Eurasian (Höwenegg, Germany; Pavlodar, Kazakhstan [small form]) material were also made. Based on their morphology, and on bivariate and multivariate analysis to establish size similarities, the Hipparion remains from Los Valles de Fuentidueña and Concud were both determined to belong to Hipparion concudense. However, differences in both dental morphology and limb slenderness could suggest differences at the subspecific level.
\end{abstract}

Keywords: Equidae, Hipparion, Multivariate analysis, Late Miocene, Los Valles de Fuentidueña, Concud, Spain.

\section{RESUMEN}

En este trabajo se realiza una comparación morfológica y biométrica de Hipparion primigenium melendezi de Los Valles de Fuentidueña (Segovia) e Hipparion concudense concudense de Concud (Teruel) con el fin de revisar la posible coespecifidad entre ellas. Se han realizado comparaciones con material de otras localidades españolas (La Roma 2, Puente Minero, Milagros, Las Casiones y Venta del Moro) y Euroasiáticas (Höwenegg, Germany; Pavlodar, Kazakhstan [forma pequeña]). A partir de los caracteres morfológicos y los análisis bivariantes y multivariantes de los restos de Hipparion de ambas localidades y su comparación con los restos de otras localidades españolas y euroasiáticas se confirma la relación coespecifica entre ambas especies de Hipparion. Sin embargo, tanto las diferencias encontradas en la morfología dental como en la gracilidad de sus metápodos podrían sugerir diferencias a nivel subespecífico.

Palabras clave: Equidae, Hipparion, Análisis multivariante, Mioceno superior, Los Valles de Fuentidueña, Concud, España.

\section{Introduction}

The genus Hipparion is recorded in Eurasia from the early Vallesian to the early Villafranchian (late Miocene-late Pliocene, sensu Bonadonna \& Alber- di, 1987). Many early Vallesian species and subspecies were proposed, but most were later grouped into the species $H$. primigenium (Alberdi, 1974; Forsten, 1968). During the Turolian, the genus diversified widely throughout Eurasia. Size reduc-

\footnotetext{
1 Fundación Conjunto Paleontológico de Teruel-Dinópolis. Avda. Sagunto s/n. 44002 Teruel. Email: pesquero@fundaciondinopolis.org

2 Museo Nacional de Ciencias Naturales (CSIC), C/ José Gutiérrez Abascal 2. 28006 Madrid. Email: mcnaa3j@mncn.csic.es
} 
tion of the medium-sized species $H$. mediterraneum and $H$. concudense, among others, led to the appearance of very small taxa such as $H$. matthewi and $H$. periafricanum.

The abundant Eurasian record of Vallesian and Turolian Hipparion gave rise to a great proliferation of taxonomic names that Forsten (1968) tried to synthesize using statistical methods. Later, using other statistical methods that combined morphological and biometric features, Alberdi (1974) set limits to Forsten's reduced systematics. Alberdi (1989) then went on to establish six morphotypes sensu lato in an attempt to unify the Eurasian and African Hipparion species appearing from the early Vallesian to the early Villafranchian. A number of authors have recently proposed these species be assigned to different genera and subgenera. Based on Hipparion remains found in China, Qiu et al. (1987) proposed grouping a number of Chinese species into different subgenera. Bernor et al. (1996, p. 333) placed all species of the genus Hipparion into the Hipparionini tribe, and grouped them into several genera or group complexes. Following Bernor et al. (1996) these include four supra-specific evolutionary complexes: the Hippotherium primigenium-Complex (with 13 taxa), the Hipparion s.s.- Group (six taxa), the Cremohipparion-Group (seven taxa), and the "Plesiohipparion"- Group (six taxa) belonging to the "Sivalhippus" Complex.

The nomenclature of Hipparion species is, however, becoming more and more complicated, a likely consequence of the philosophical differences in taxonomic meaning employed when comparing genera and species. The examination of the morphological features of many remains of Hipparion could, however, provide a global framework for defining the morphotype of Hipparion sensu lato (see Pesquero et al., 2006, 2007).

The Turolian mammal site of Concud, in the northeast of the Teruel Province, Spain, is home to accumulations of vertebrate bones, the richness, diversity, and special features of which render the faunal assemblages recorded a reference for studies on Eurasian Neogene mammals. The site is the type-locality of Canis cipio (the oldest canid - Caninae sensu stricto - of the fossil record), of the bovid Hispanodorcas torrubiae, of Turiacemas concudensis (one of the oldest three-tined deer), and of the tridactyl equid Hipparion concudense. The fossiliferous level was deposited during the progressive transition between alluvial and shallow lake envi- ronments. The mammal assemblages, similar to that found at Los Mansuetos locality, typify the middle Turolian (MN12) (Alcalá, 1998; Alcalá et al., 1999; Pesquero et al., 2010).

The Vallesian mammal site of Los Valles de Fuentidueña (Segovia Province), located in the upper part of the Duero Basin, reflects a pond system, the bone material of which was provided via a small alluvial fan coming from a Cretaceous calcareous palaeorelief (Hoyos et al., 1981). This site contains the remains of a diversified fauna of micro- and macromammals, and is highly important for the characterization of the early Vallesian of the Duero Basin as it allows correlations with faunal assemblages of the same age in other basins. The analysis of this fauna indicates that, during the late Aragonian and early Vallesian, the Duero Basin fauna was similar to that of the Calatayud-Teruel Basin. In fact, both can be included within a single biogeographic unit. This unit, however, shows clear differences to the faunal composition of the VallésPenedés Basin, which is more similar to German and French basins of the same age (Alberdi et al., 1981).

The main aim of this paper is to review the Los Valles de Fuentidueña and Concud remains of Hipparion, checking against the work of Forsten (1982), who indicated a conspecific relationship between Hipparion concudense (Pirlot, 1956) from Concud and Hipparion primigenium melendezi (Alberdi, 1974) from Los Valles de Fuentidueña, referred to by Eisenmann (1995) as Hipparion melendezi.

\section{Material and Methods}

\section{Material}

The studied material comes from the Spanish fossil sites of Los Valles de Fuentidueña (Segovia) (Alberdi, 1974) and Concud (Teruel) (Alberdi, 1974; Alcalá, 1994) (fig. 1). This material is stored at the Museo Nacional de Ciencias Naturales, CSIC, Madrid.

Specimens from Los Valles de Fuentidueña. Upper teeth: 64 P3-4, 128 M1-2. Lower teeth: 66 p3-4, 107 m1-2. Appendicular skeleton: one distal humeral fragment, two proximal radial fragments, $35 \mathrm{McIII}$ (ten complete), seven calcanei, 28 astragali, 49 MtIII (15 complete), seven 1PhIII, 13 first lateral phalanges, 39 2PhIII, 13 second lateral phalanges, one 3PhIII, 16 scaphoids, one magnum, six lunata, six pisiforms, six ectocuneiforms, 12 naviculars, and seven cuboids.

Specimens from Concud. Upper teeth: 128 P3-4, 121 M1-2. Lower teeth: 97 p3-4, 102 m1-2. Appendicular skeleton: 23 humeral fragments, 52 radial fragments, eight femur fragments, 


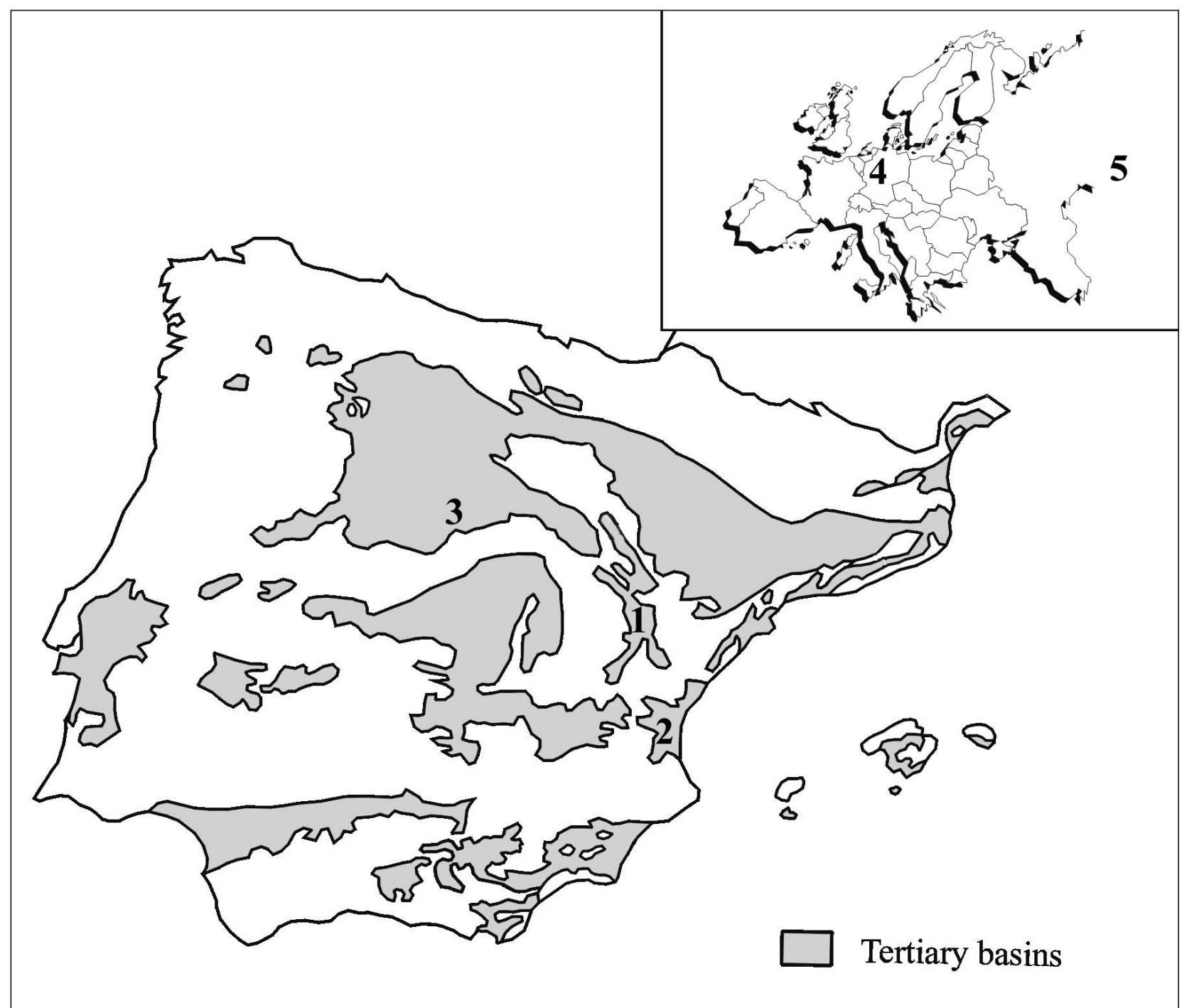

Figure 1.-Geographic location of the sites - 1, Teruel area: Concud (CD), La Roma 2 (RO2), Puente Minero (PM), Milagros (ML), and Las Casiones (KS); 2, Venta del Moro (VM); 3, Los Valles de Fuentidueña (LVF); 4, Höwenegg (HO); 5, Pavlodar (PAV).

22 McIII (seven complete), one tibia and 24 fragments, 12 calcanei, 45 astragali, 22 MtIII (ten complete), 50 1PhIII, 86 first lateral phalanges, 94 2PhIII, 20 second lateral phalanges, 12 3PhIII, three third lateral phalanges, 40 scaphoid, 50 magna, 49 lunata, 14 pisiforms, 18 trapezoids, 66 ectocuneiforms, 83 naviculars, and 66 cuboids.

Material for comparison. This study compars the specimens from these localities with material from other Spanish sites in order to increase the reference framework and render multivariate analysis for establishing size limits more reliable. The Vallesian-Turolian forms from these sites include Hipparion laromae from la Roma 2 (Pesquero et al., 2006), Hipparion laromae from Puente Minero (Pesquero et al., 2011), Hipparion matthewi from Milagros; Hipparion matthewi from Las Casiones; and Hipparion matthewi from Venta del Moro (Pesquero, 2003; Pesquero et al., 2007). From Central Europe and Asia, specimens of Hipparion primigenium (or Hippotherium primigenium sensu Bernor et al., 1996) from Höwenegg (Germany; Bernor et al., 1997; plus raw data kindly sent by Bernor) and Hipparion matthewi from Pavlodar, Kazakhstan (Orlov, 1936; plus our own data) were examined.

\section{Methodology}

The morphological and morphometric traits (fig. 2) proposed by Alberdi (1974) were examined. The hypsodonty index was calculated for unworn or only slightly worn teeth. This index is defined as the ratio between the mesio-distal length (2) and the height of the unworn teeth (1) (Eisenmann et al., 1988: Figs. 68 ). The dimensions of the teeth are presented in a bivariate plot using the customary P3-4, M1-2, p3-4, and m1-2 teeth. Two bivariate plots were generated to analyse the robustness or gra- 

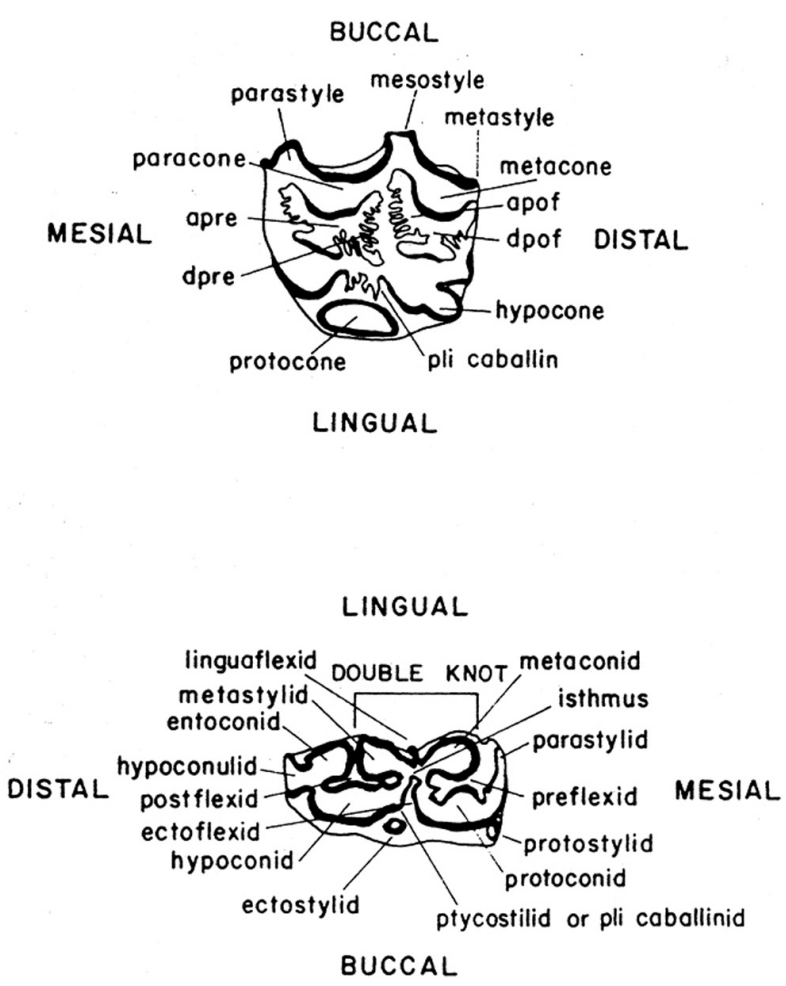

Figure 2.-Morphological characteristics of the upper (top) and lower (bottom) cheek teeth of Hipparion.

cility of the metapodials. One plot, produced according to Bernor et al. (1990), juxtaposed the maximum length (McIII1 or MtIII1) against the distal articular breadth (McIII11 or MtIII11). The second compared the maximum length against the minimal breadth of the diaphysis (McIII3 or MtIII3). Bivariate and multivariate analyses were performed with the numerical data to establish size similarities. Metapodials, astragali, calcanei and first phalanges were analysed using principal component analysis (PCA) to evaluate size similarities and/or differences among the different Hipparion remains. Groups were identified based on the outcome of PCA, and discriminant analysis (DA) then preformed using the Mahalanobis method with the aim of maximizing the separation between them. This determines whether the centroids differ significantly or not, and often identifies specimens not included in the original PCA. Body masses were estimated using the first phalanx, the Ph5 measurement $(\mathrm{r}=0.991)$, and McIII and MCIII13 measurements $(r=0.982)$, according to Alberdi et al. (1995). Calculations were made using SPSS 15.0.

The nomenclature and measurements follow the recommendations of the "Hipparion Conference", New York, November 1981 (Eisenmann et al., 1988). All dimensions are expressed in millimetres.

\section{Abbreviations}

P/M: upper cheek teeth; $\mathrm{p} / \mathrm{m}$ lower cheek teeth; L: length; B: breadth; HI: hypsodonty index; Apre: anterior-prefossette;
Dpre: distal-prefossette; Apof: anteriorpostfossette; Dpof: distal-postfossette; McIII and MtIII: metacarpal and metatarsal of the third digit respectively; GI: gracility index; $1 \mathrm{PhIII}, 2 \mathrm{PhIII}$ and 3PhIII: first, second and third phalanges of the third digit respectively; PCA: principal components analysis; DA: discriminant analysis.

Localities: CD: Concud; HO: Höwenegg; KS: Las Casiones; LVF: Los Valles de Fuentidueña; ML: Milagros; PAV: Pavlodar; PM: Puente Minero; RO2: La Roma 2; VM: Venta del Moro.

\section{Systematic Palaeontology}

Order PERISSODACTYLA Owen, 1848

Infraorder HIPPOMORPHA Wood, 1937

Superfamily EQUOIDEA Gray, 1821

Family EQUIDAE Gray, 1821

Genus HIPPARION Christol, 1832

Hipparion concudense Pirlot, 1956

Hipparion concudense melendezi Alberdi, 1974

Synonymy list:

1926 Hipparion gracile Kaup; Royo Gómez.

1944 Hipparion gracile Kaup; Meléndez, Crusafont and Villalta. 1944 Hipparion gracile Kaup; Almela, Bataller and Sampelayo. 1948 Hipparion gracile Kaup; Villalta and Crusafont.

1952 Hipparion gracile Kaup; Crusafont.

1968 Hipparion sp. Crusafont, Aguirre and García.

1974 Hipparion primigenium melendezi Alberdi; Alberdi.

Holotype: Right MtIII (MNCN-30654; ancient number collection: LVF-15019 and H- 988), stored at MNCN Collection. Referred to in Alberdi (1974: Lam 2-3 and Fig. 7).

Type locality: Los Valles de Fuentidueña, Segovia, Spain.

Stratigraphic distribution: Vallesian (late Miocene).

Geographic distribution: Spain.

Material: Specified in the "Materials and Methods" sections.

Description: The protocone shape is oval in premolars and molars, sometimes connected to the protoloph in stage of wear II in P2 and in stage of wear III in P3-4 and M1-2. In M1-2, the fossette folds show medium folding varying from 0 to 7 at Apre, 2-11 at Dpre, 2-7 at Apof, and 0-3 at Dpof. The modes are 2 plus 3, 7, 5, and 1 respectively. In P3-4, the fossette folds show medium folding varying from 0 to 3 at Apre, 3-10 at Dpre, 1-8 at Apof, and 0-3 at Dpof. The modes are 1, 6, 3, and 1 respectively. The pli caballin varies between 1 and 4, while the mode for premolars is 2 and for molars is 1 . Hypsodonty index 2.1 in P3-4 and 2.5 in M1-2. In the lower cheek teeth the enamel is complex. Protostylid isolated on occlusal surface of unworn teeth, only joined to protoconid in stages of wear III. Hypsodonty index 2.2 in p3-4 and 2.4 in m1-2.

Postcranial remains are medium-sized and slender. Metapodials are elongated and slender. In McIII proximal articulation, the angle between the magnum and unciform facets varies from $124^{\circ}$ to $134^{\circ}$. The gracility index of McIII $1 / \mathrm{McIII} 3$ varies from 10.6 to12.3 ( $\mathrm{X}=11.3$ ); that of McIII1/McIII11 is 15.2 (only one specimen was available). 
Table 1.-Hypsodonty index of Spanish Hipparion. $\mathbf{N}=$ number of specimens; Sd = standard deviation; $\mathbf{X}=$ mean

\begin{tabular}{|c|c|c|c|c|c|c|c|c|c|c|c|c|}
\hline & \multicolumn{3}{|c|}{ H. laromae (RO2) } & \multicolumn{3}{|c|}{ H. laromae $(\mathrm{PM})$} & \multicolumn{3}{|c|}{ H. primigenium $(\mathrm{NO})$} & \multicolumn{3}{|c|}{ Hipparion (LVF) } \\
\hline & $\mathrm{N}$ & $\mathrm{Sd}$ & $X$ & $\mathrm{~N}$ & $\mathrm{Sd}$ & X & $\mathrm{N}$ & $\mathrm{Sd}$ & $\mathrm{X}$ & $\mathrm{N}$ & $\mathrm{Sd}$ & $\mathrm{X}$ \\
\hline P3-4 & - & - & - & (2) & 0.13 & 2.4 & (6) & 0.14 & 1.8 & $(5)$ & 0.08 & 2.1 \\
\hline M1-2 & - & - & - & (2) & 0.08 & 2.6 & (6) & 0.14 & 2.5 & (25) & 0.14 & 2.5 \\
\hline p3-4 & (1) & - & 2 & (2) & 0.09 & 2.5 & (2) & 0.11 & 2.1 & (4) & 0.06 & 2.2 \\
\hline \multirow[t]{3}{*}{ m1-2 } & (1) & - & 2.2 & (2) & 0.04 & 2.6 & (3) & 0.1 & 2.4 & $(21)$ & 0.16 & 2.4 \\
\hline & \multicolumn{3}{|c|}{ Hipparion (CD) } & \multicolumn{3}{|c|}{ H. matthewi (VM) } & \multicolumn{3}{|c|}{ H. matthewi (KS) } & \multicolumn{3}{|c|}{ H. matthewi (ARQ) } \\
\hline & $\mathrm{N}$ & $\mathrm{Sd}$ & $\mathrm{X}$ & $\mathrm{N}$ & $\mathrm{Sd}$ & X & $\mathrm{N}$ & $\mathrm{Sd}$ & $\mathrm{X}$ & $\mathrm{N}$ & $\mathrm{Sd}$ & $\mathrm{X}$ \\
\hline P3-4 & (13) & 0.13 & 2.5 & (1) & - & 2.5 & (3) & 0.11 & 2.5 & (3) & 0.1 & 2.7 \\
\hline M1-2 & (19) & 0.12 & 2.6 & (9) & 0.04 & 2.4 & (17) & 0.16 & 2.7 & (10) & 0.11 & 2.8 \\
\hline p3-4 & (16) & 0.09 & 2.4 & (1) & - & 2.5 & $(2)$ & 0.16 & 2.3 & $(1)$ & - & 2.7 \\
\hline $\mathrm{m} 1-2$ & (19) & 0.12 & 2.6 & (5) & 0.16 & 2.7 & (14) & 0.18 & 2.7 & (3) & 0.05 & 2.8 \\
\hline
\end{tabular}

Proximal articulation surface of MtIII shows a well developed cuboid facet. A small cuneiform facet is present in two specimens (four in total). Gracility index of MtIII1/MtIII3 varies from 9.4 to10.8 (X = 10.3); that of MtIII1/MtIII11 varies from 13.9 to $14.8(X=14.4)$.

\section{Hipparion concudense concudense Pirlot, 1956}

Synonymy list:

1850. Hippotherium gracile Kaup; Ezquerra del Bayo.

1852. Hipparion prostylum Gervais; Gervais.

1885. Hipparion gracile Kaup; Cortazar.

1903. Hipparion gracile Kaup; Woodward.

1914. Hipparion gracile Kaup; Hernández-Pacheco.

1947. Hipparion gracile Kaup; Villalta and Crusafont.

1952. Hipparion mediterraneum Roth \& Wagner, not Hensel; Crusafont.

1954. Hipparion mediterraneum Roth \& Wagner, not Hensel; Crusafont and Truyols.

Holotype: Not defined

Lectotype: Cheek tooth row (P40-1960) stored at IPPS. Referred to in Sondaar (1961: p. 229, Fig. 7a, Lam. IC).

Type locality: Concud, Teruel, Spain.

Stratigraphic distribution: Turolian (late Miocene).

Geographic distribution: Spain.

Material: Specified in the "Materials and Methods" sections.

Description: The protocone shape is oval, becoming quadrangular with wear. Sometimes connected to the protoloph in advanced stages of wear. M1-2 show deep-medium fossette folds varying from 1to 6 at Apre, 2-12 at Dpre, 1-10 at Apof, and $0-4$ at Dpof. The modes are 4, 6 plus 7, 5, and 1 respectively. In P3-4 the fossette folds vary from 0 to 9 at Apre, 3-14 at Dpre, 1-9 at Apof, and 0-4 at Dpof. The modes are 1, 7, 5, and 1 respectively. The pli caballin varies between 1 and 5 , while the mode for both premolars and molars is 1 . Hypsodonty index 2.5 in $\mathrm{P} 3-4$ and 2.6 in $\mathrm{M} 1-2$.
Lower cheek teeth are medium-sized. Occlusal morphology not complicated. Molars with a protostylid isolated on occlusal surface in unworn teeth, only joined to protoconid in stage of wear I in molars and II in premolars. Hypsodonty index 2.4 in p3-4 and 2.6 in $\mathrm{m} 1-2$.

Appendicular skeleton remains well preserved, characterizing an animal of medium size. In McIII proximal articulation, the angle between the magnum and unciform facets is $130^{\circ}$. The gracility index of McIII1/McIII3 varies from 11.2 to14.5 (X = 12.7); that of McIII1/McIII11 varies from 13.9 to 16.7 (X = 15.9). In MtIII, cuboid facet not well developed. Gracility index of MtIII1/MtIII3 varies from 10.7 to12.7 (X = 11.8); that of MtIII1/MtIII11 varies from 14.1 to 15.3 (X=14.8).

\section{Results}

\section{Morphological and univariate analysis}

Morphological analysis revealed similarities in skeletal structure between the Hipparion remains from LVF and CD. Both show similar occlusal tooth morphology, although the enamel is more complicated in the LVF lower cheek teeth. Hipparion from LVF differs from $H$. primigenium from Nombrevilla in Spain and HO in Central Europe (Pesquero et al., 2006), which tend to have a more complicated enamel pattern on the occlusal surface (Alberdi, 1974).

The hypsodonty index indicates that, in general, the teeth of the CD form are somewhat more hypsodont than those from LVF (table 1), and that both CD and LVF teeth are more hypsodont than those of either H. primigenium from Nombrevilla (Pesquero et al., 2006) or H. laromae from $\mathrm{RO} 2$, and similar to those of $H$. laromae from PM.

The bivariate plot of the dental measurements indicates that the remains of Hipparion from LVF 

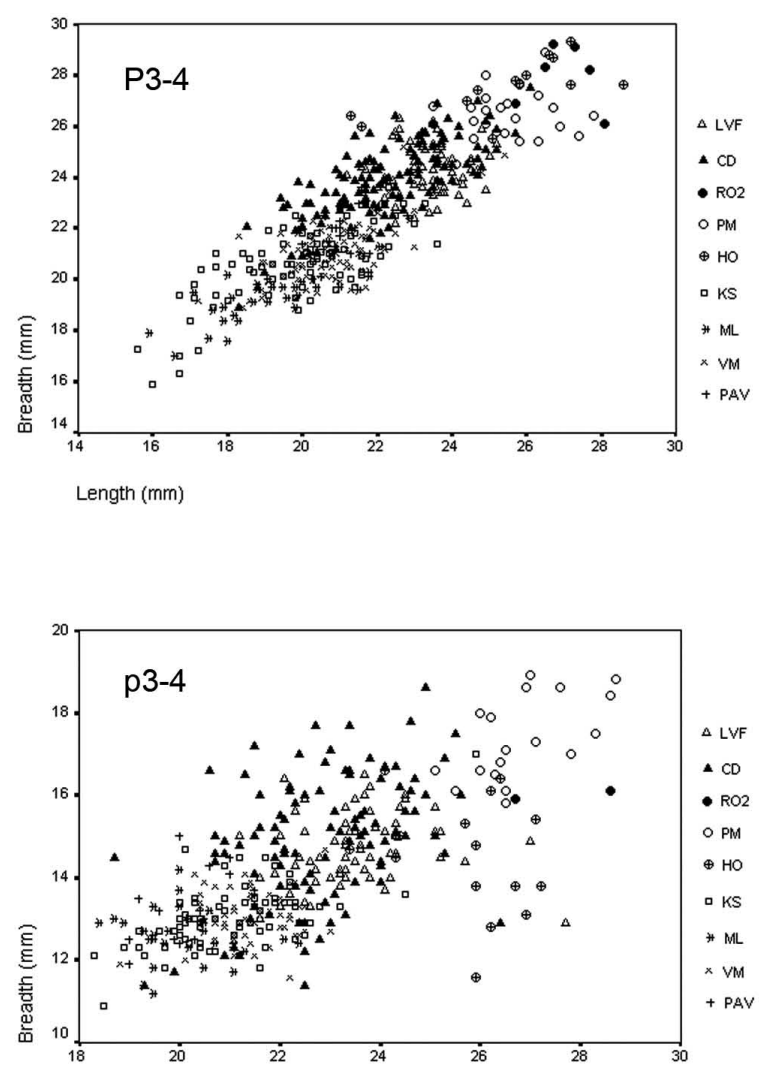

Length (mm)
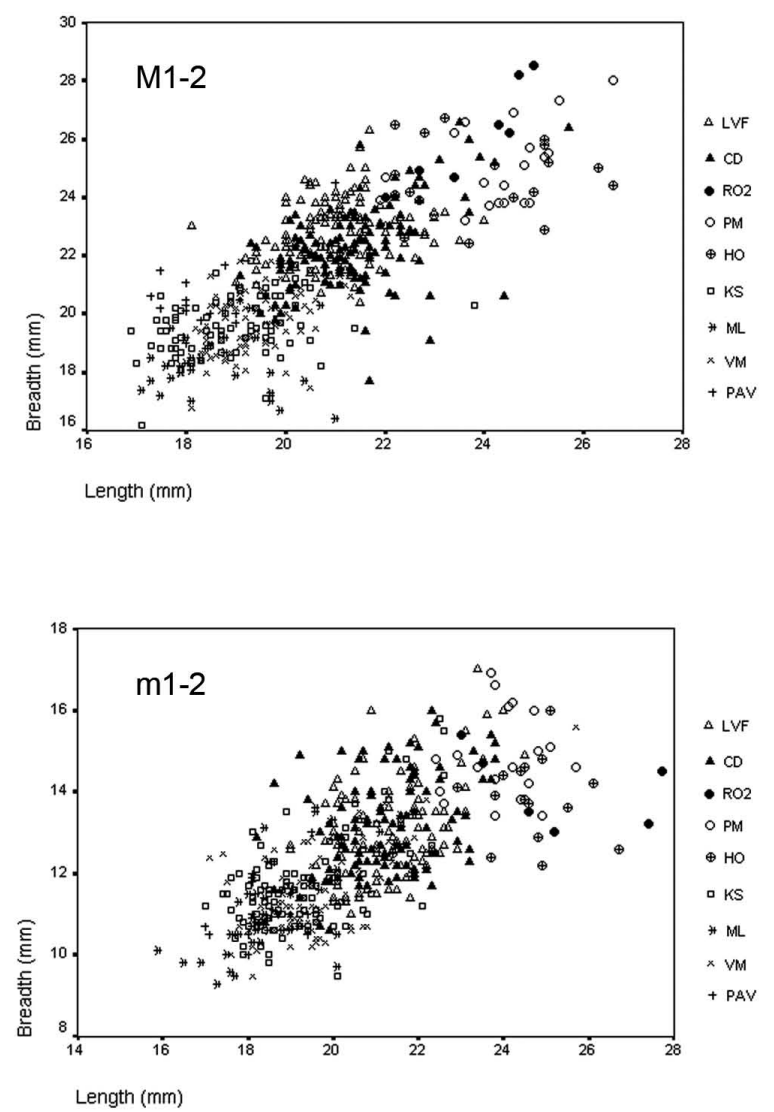

Figure 3.-Occlusal length vs. occlusal breadth plotted for upper and lower cheek teeth (P3-4, M1-2, p3-4, m1-2) of Spanish and Eurasian Hipparion material.

clearly fall within the distribution of the CD remains. In both forms the length and breadth of the lower and upper cheek teeth are similar. The teeth of Hipparion from CD and LVF are larger than those of $H$. matthewi from KS, ML, VM, and PAV and clearly rest outside of the distribution of $H$. primigenium from $\mathrm{HO}$ and $H$. laromae from $\mathrm{RO} 2$ and PM (fig. 3).

The bivariate plots for McIII and MtIII indicate differences between the LVF and CD Hipparion remains and those from the other sites (fig. 4). The McIII from LVF and CD are longer than those of $H$. matthewi from KS, ML, VM, and PAV, and similar to that of $H$. primigenium from HO. Nevertheless, the diaphysis breadth of the LVF and CD forms is larger than that of $H$. matthewi from VM and smaller than that of $H$. primigenium from $\mathrm{HO}$, this is, the McIII from LVF and CD are slender than those from HO. Only one McIII from CD is similar in length and breadth to those from HO. The MtIII of LVF and CD forms clearly lie outside the distribution of the H. matthewi and $H$. laromae remains. In both Spanish forms the length of the MtIII is similar, but the breadth is wider in CD metatarsals than in the LVF samples and closer to that of $H$. primigenium from $\mathrm{HO}$, although the latter has greater length.

The gracility index indicates the LVF specimens to be more slender than those of CD. Both forms are more slender than $H$. primigenium from $\mathrm{HO}$ and more robust than $H$. matthewi from KS, ML, VM, and PAV (table 2).

The analysis of body mass following the methodology of Alberdi et al. (1995) indicated the LVF and CD forms to be of similar weight, while both are considerably smaller than $H$. laromae from $\mathrm{RO} 2$ and $\mathrm{PM}$ or $\mathrm{H}$. primigenium from $\mathrm{HO}$, but larger than $H$. matthewi from KS, ML, and VM.

\section{Multivariate analysis}

Principal component analysis of the skeletal measurements identified four main groups based on size 


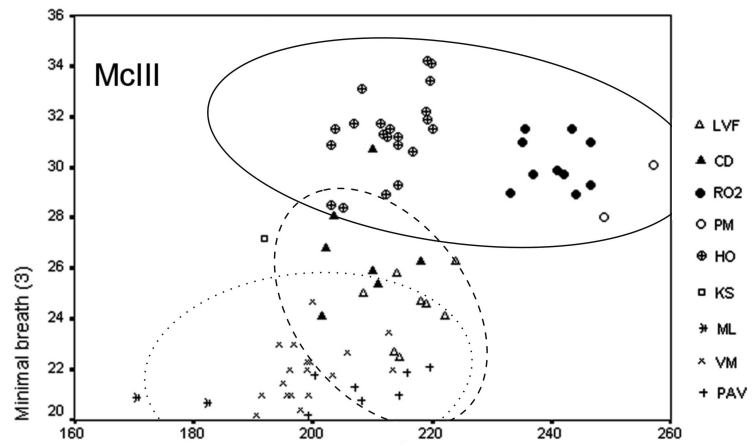

Maximal length (1)

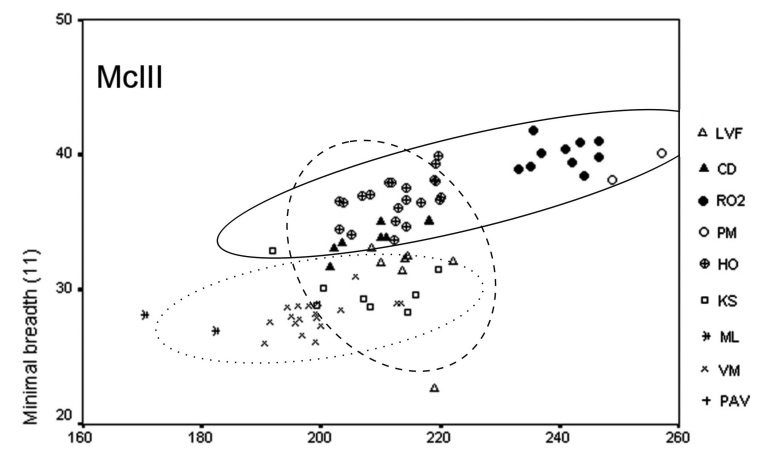

Maximal length (1)

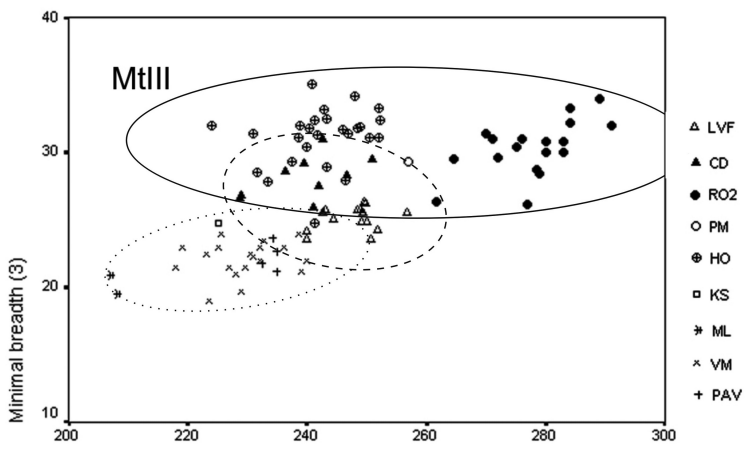

Maximal length (1)

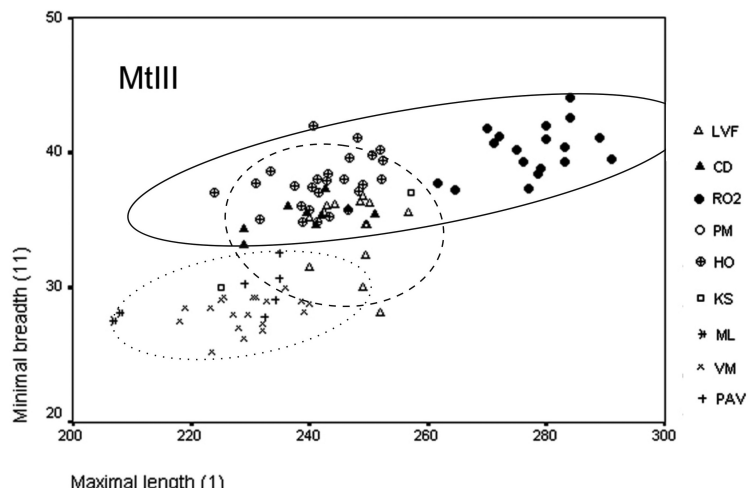

Figure 4.-Scatter diagram of Mclll and MtIII (dimension 1 vs. dimension 3, and dimension 1 vs. dimension 11) of Spanish, and Eurasian Hipparion material.

Table 2.-Gracility index and body mass estimation of Spanish, European, and Asian Hipparion. Abbreviations as in Table 1

\begin{tabular}{|c|c|c|c|c|c|c|c|c|c|c|c|c|c|c|}
\hline & \multicolumn{3}{|c|}{ MtIII1/MtIII3 } & \multicolumn{3}{|c|}{ McIII1/McIII3 } & \multicolumn{3}{|c|}{ MtIII1/MtIII11 } & \multicolumn{3}{|c|}{ McIII1/McIII11 } & \multicolumn{2}{|c|}{ Body mass (Kg.) } \\
\hline & (min.) & $\mathrm{X}$ & $(\max )$. & $(\min )$. & $\mathrm{X}$ & (max.) & (min.) & $X$ & (max.) & (min.) & $\mathrm{X}$ & $(\max )$. & $\begin{array}{c}1 \mathrm{FII} \\
(5)\end{array}$ & $\begin{array}{c}\text { McIII } \\
(13)\end{array}$ \\
\hline $\begin{array}{c}\text { Puente Minero } \\
\text { (H. laromae) }\end{array}$ & - & 11.4 & - & 11.3 & 11.5 & 11.7 & - & 14.4 & - & 15.3 & 15.5 & 15.6 & 331 & 338 \\
\hline La Roma 2 (H. laromae) & 9.2 & 10.8 & 11.7 & 11.9 & 12.5 & 13.4 & 13.5 & 14.4 & 15.5 & 15.7 & 17.2 & 17.7 & 349 & 328 \\
\hline $\begin{array}{l}\text { Howenegg } \\
(H, \text { primigenium })\end{array}$ & 10.3 & 12.8 & 14.5 & 13.6 & 14.7 & 15.89 & 14.5 & 15.6 & 15.9 & 15.9 & 17.2 & 18.2 & 277 & 236 \\
\hline $\begin{array}{l}\text { Nombrevilla } \\
\text { (H.primigenium })\end{array}$ & - & 12.6 & - & - & 13.8 & - & - & - & - & - & - & - & 178 & - \\
\hline L.V.F. & 9.4 & 10.3 & 10.8 & 10.6 & 11.3 & 12.3 & 13.9 & 14.4 & 14.8 & - & 15.2 & - & 170 & 186 \\
\hline Concud & 10.7 & 11.8 & 12.7 & 11.2 & 12.7 & 14.5 & 14.1 & 14.8 & 15.3 & 13.9 & 15.9 & 16.7 & 160 & 178 \\
\hline $\begin{array}{l}\text { Venta del Moro } \\
\text { (H. matthewi) }\end{array}$ & 9 & 9.5 & 10.1 & 9.8 & 10.2 & 10.8 & 12 & 12.8 & 13.9 & 13.2 & 14.1 & 15 & 111 & 123 \\
\hline $\begin{array}{l}\text { Las Casiones } \\
\text { (H. matthewi) }\end{array}$ & - & 11 & - & - & 14.2 & - & - & 13.3 & - & - & 17.1 & - & 117 & 117 \\
\hline Milagros (H. matthewi) & 9.4 & 9.7 & 10.1 & 11.3 & 11.8 & 12.2 & 13.3 & 13.4 & 13.5 & 14.7 & 15.6 & 16.5 & 75 & 114 \\
\hline Pavlodar (H. matthewi) & 9.5 & 9.5 & 9.5 & 10.6 & 10.9 & 11.3 & 12.9 & 12.9 & 13 & 14.3 & 14.6 & 14.9 & 121 & 133 \\
\hline
\end{tabular}




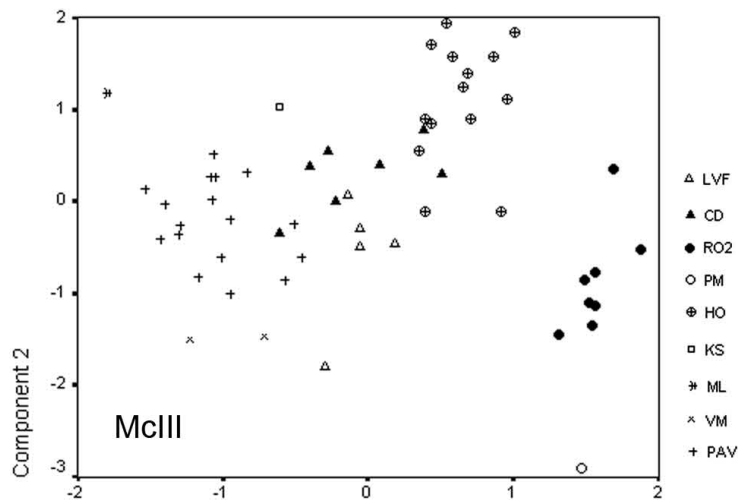

Component 1

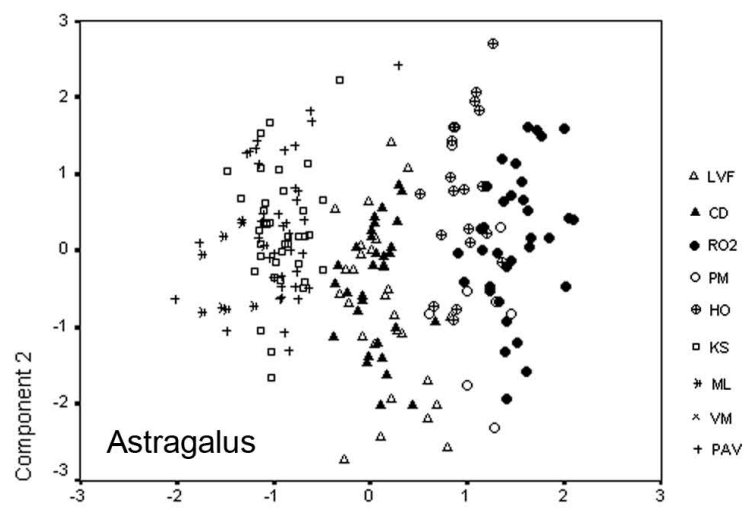

Component 1

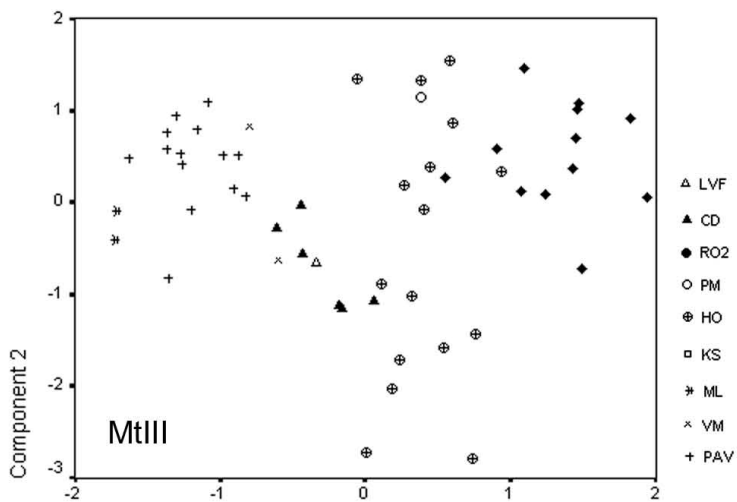

Component 1

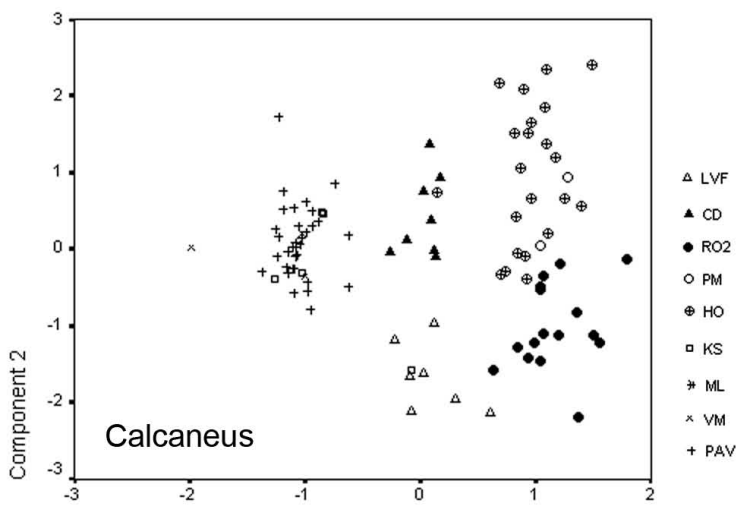

Component 1

Figure 5.-Principal component analysis of Mclll, MtIII, astragalus, and calcaneus.

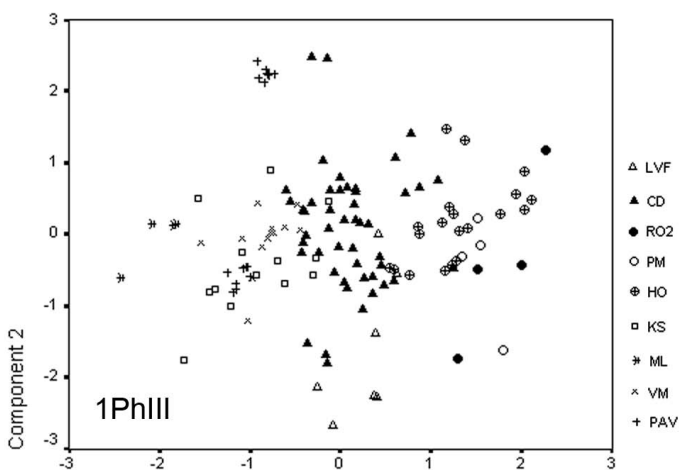

Component 1

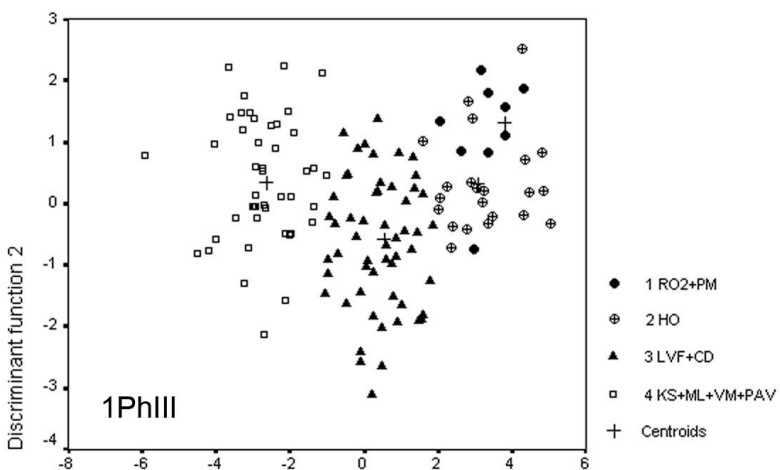

Discriminant function 1

Figure 6.-Principal component analysis for the first phalanx III and discriminant analysis based on PCA results.

(figs. 5 and 6). The first clustered the specimens belonging to the large PM and RO2 forms, while the second contained the specimens from HO. The third group included the LVF and CD forms, and the fourth group contained the relatively small specimens of $H$. matthewi from VM, KS, PAV, and ML.
In the PCA for McIII, all variables influenced the first component with the skeletal size carrying the greatest weight (fig. 5, table 3). The most influential traits were the proximal articular breadth (McIII5), the proximal articular depth (McIII6), and the maximal distal depth of the medial condyle (McIII14). 
Table 3.-Most influential traits with respect to components1 and 2 in PCA

\begin{tabular}{|c|c|c|c|c|c|}
\hline $\begin{array}{l}\text { Principal } \\
\text { component } \\
\text { of limb } \\
\text { bones }\end{array}$ & $\begin{array}{l}\text { Number of } \\
\text { character }\end{array}$ & Eigen value & $\begin{array}{l}\text { Principal } \\
\text { component } \\
\text { of limb } \\
\text { bones }\end{array}$ & $\begin{array}{l}\text { Number of } \\
\text { character }\end{array}$ & Eigen value \\
\hline McIII & & & Astragalus & & \\
\hline \multirow[t]{3}{*}{ First component } & 5 & 0.971 & First component & 2 & 0.978 \\
\hline & 6 & 0.962 & & 5 & 0.973 \\
\hline & 14 & 0.952 & & 4 & 0.971 \\
\hline \multirow[t]{4}{*}{ Second component } & 8 & 0.511 & Second component & 3 & 0.318 \\
\hline & 3 & 0.363 & & 4 & 0.058 \\
\hline & 11 & 0.168 & Calcaneus & & \\
\hline & & & First component & 1 & 0.976 \\
\hline MtIII & & & & 5 & 0.963 \\
\hline \multirow[t]{3}{*}{ First component } & 7 & 0.980 & Second component & 3 & 0.427 \\
\hline & 10 & 0.969 & & 4 & 0.195 \\
\hline & 12 & 0.966 & First phalanx & & \\
\hline \multirow[t]{5}{*}{ Second component } & 9 & 0.593 & First component & 7 & 0.968 \\
\hline & 8 & 0.319 & & 4 & 0.963 \\
\hline & 2 & 0.225 & & 6 & 0.953 \\
\hline & & & Second component & 2 & 0.623 \\
\hline & & & & 1 & 0.540 \\
\hline
\end{tabular}

These components clearly separate the McIII of the large PM and RO2 forms from the rest of the smaller remains. The McIII of $\mathrm{HO}$ fell in-between. The second component was mainly influenced by the diameter of the anterior facet of the fourth carpal (McIII8) and the minimal breadth (McIII3).

The results for the PCA of MtIII were similar to those of the McIII (fig. 5, table 3). In the first component the most influential character was size. The most influential variables were the maximal diameter of the articular facet for the third tarsal (MtIII7), the maximal distal supra-articular breadth (MtIII10), and the maximal distal articular breadth (MtIII11). In the second component the most important variables were the diameters of the articular facets for the second and fourth tarsals (MtIII 8 and MtIII9) and the maximal lengths (MtIII2 and MtIII1). In this analysis the large PM specimen fell among the values for the HO remains, those from LVF grouped with those from CD, and those from VM, ML, and PAV were clearly separated.

In the PCA for the astragalus, the distributions were similar to those recorded in the analysis of MtIII (fig. 5, table 3). All variables influenced the first component, emphasizing the size of the different specimens. The breadth of the trochlea (AS3) carried the most weight in the second component.

In the PCA for the calcaneus the distribution was again similar (fig. 5, table 3). All variables influenced the first component; the minimal breadth
(CAL3) carried the most weight in the second component.

In the PCA for the first phalanx the most influential variable in the first component was skeletal size (fig. 6, table 3). The maximal length was the most important variable (1PhIII1) in the second component. In figure 6 , the results for the $1 \mathrm{PhIII}$ PCA are similar to those for the calcaneus and astragalus in general terms, but the PCA for 1PhIII indicated large differences between the anterior and posterior phalanges.

Discriminant analysis was performed on the PCA results to maximize the separation among the groups produced. The first group included the largest remains, i.e., those from $\mathrm{RO} 2$ and $\mathrm{PM}$; the second included the large sized remains from $\mathrm{HO}$, the third consisted of the relatively middle remains from LVF and CD, and the fourth included the small-sized remains from VM, KS, ML, and PAV.

The DA for McIII clearly separated the LVF and CD group from the samples of $H$. primigenium from $\mathrm{HO}$, and indeed from other sites (fig. 7, table 4). The results indicate this group to be well classified in $91.7 \%$ of cases, with only one of 12 specimens overlapping with some of $H$. primigeni$u m$ from HO. The first and the second group were always correctly identified. The DA for MtIII reproduced these results. Only one specimen out of 13 (7.1\%) from the third group overlapps with some specimens of $H$. primigenium from $\mathrm{HO}$ (fig. 7 , 


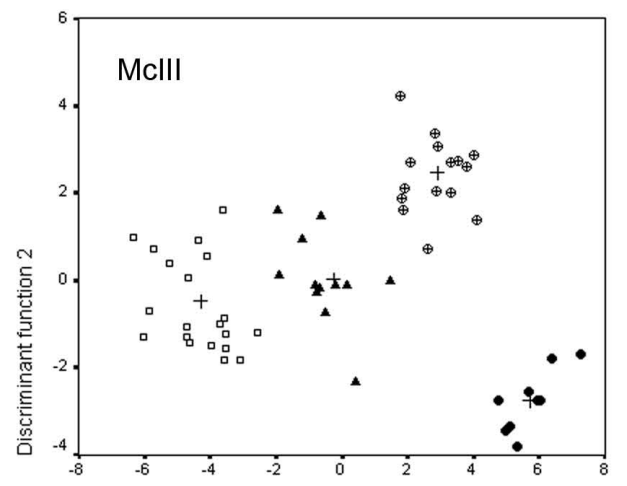

Discriminant function 1

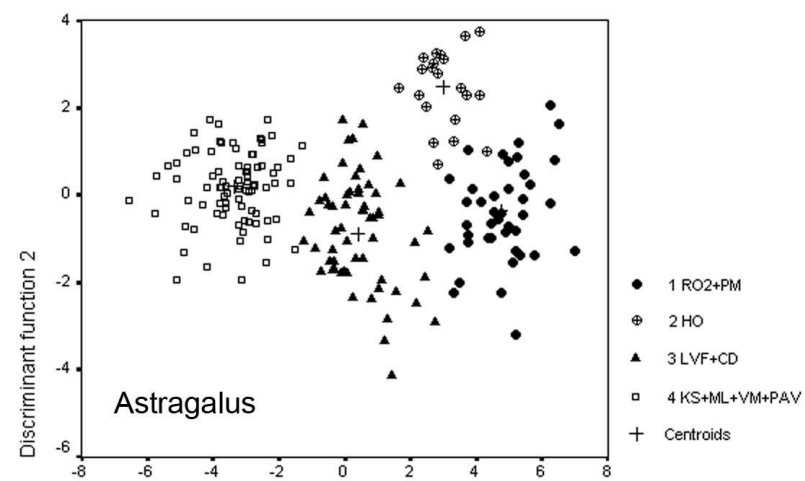

Discriminant function 1

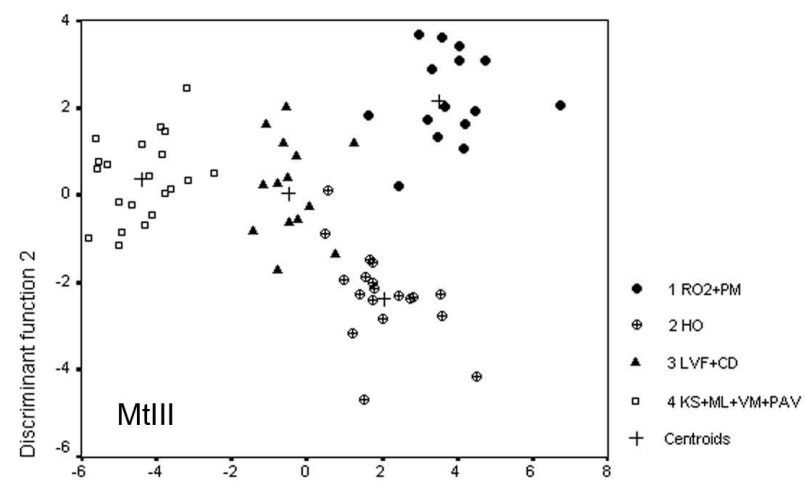

Discriminant function 1

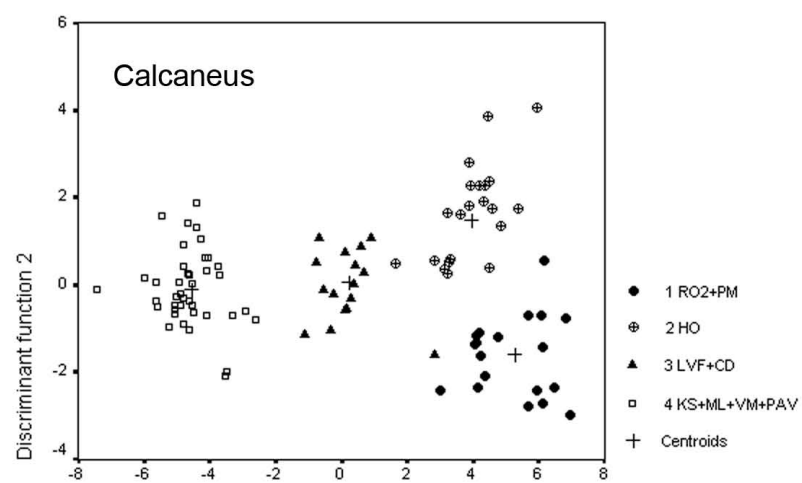

Discriminant function 1

Figure 7.-Discriminant analysis based on PCA results for MtIII, Mclll, astragalus and calcaneus.

Table 4.-Percentage of correct classification as determined by cross-validation. 1: Hipparion laromae (RO2+PM); 2: Hipparion concudense (CD+LVF); 3: Hipparion primigenium (HO); 4: Hipparion matthewi (VM+KS+ML+PAV)

\begin{tabular}{|c|c|c|c|c|c|c|}
\hline & Original & $\mathrm{N}$ & 1 & 2 & 3 & 4 \\
\hline \multirow[t]{4}{*}{ McIII } & 1 & 9 & $100 \%$ (9) & $0 \%$ & $0 \%$ & $0 \%$ \\
\hline & 2 & 14 & $0 \%$ & $100 \%(14)$ & $0 \%$ & $0 \%$ \\
\hline & 3 & 12 & $0 \%$ & $8.3 \%(1)$ & $91.7 \%(11)$ & $0 \%$ \\
\hline & 4 & 12 & $0 \%$ & $0 \%$ & $4.8 \%(1)$ & $95.2 \%(20)$ \\
\hline \multirow[t]{4}{*}{ MtIII } & 1 & 17 & $94.1 \%(16)$ & $0 \%$ & $5.4 \%(1)$ & $0 \%$ \\
\hline & 2 & 19 & $0 \%$ & $100 \%$ (19) & $0 \%$ & $0 \%$ \\
\hline & 3 & 14 & $0 \%$ & $7.1 \%(1)$ & $92.9 \%(13)$ & $0 \%$ \\
\hline & 4 & 21 & $0 \%$ & $0 \%$ & $0 \%$ & $100 \%(21)$ \\
\hline \multirow[t]{4}{*}{ Astragalus } & 1 & 42 & $9.2 \%(39)$ & $4.8 \%(2)$ & $2.4 \%(1)$ & $0 \%$ \\
\hline & 2 & 20 & $5 \%(1)$ & $95 \%$ (19) & $0 \%$ & $0 \%$ \\
\hline & 3 & 59 & $1.7 \%(1)$ & $0 \%$ & $96.6 \%(57)$ & $1.7 \%(1)$ \\
\hline & 4 & 85 & $0 \%$ & $0 \%$ & $1.2 \%(1)$ & $98.8 \%(84)$ \\
\hline \multirow[t]{4}{*}{ Calcaneus } & 1 & 18 & $100 \%(18)$ & $0 \%$ & $0 \%$ & $0 \%$ \\
\hline & 2 & 22 & $4.5 \%(1)$ & $95.5 \%(21)$ & $0 \%$ & $0 \%$ \\
\hline & 3 & 15 & $0 \%$ & $0 \%$ & $100 \%(15)$ & $0 \%$ \\
\hline & 4 & 41 & $0 \%$ & $0 \%$ & $2.4 \%(1)$ & $97.6 \%(40)$ \\
\hline First & 1 & 8 & $75 \%(6)$ & $85 \%$ (2) & $0 \%$ & $0 \%$ \\
\hline \multirow[t]{3}{*}{ phalanx } & 2 & 20 & $10 \%(2)$ & $85 \%$ (17) & $5 \%(1)$ & $0 \%$ \\
\hline & 3 & 56 & $18 \%$ (1) & $5.4 \%(3)$ & $91.1 \%(51)$ & $1.8 \%(1)$ \\
\hline & 4 & 47 & $0 \%$ & $0 \%$ & $6.4 \%(3)$ & $93.6 \%(44)$ \\
\hline
\end{tabular}


table 4). The DA for the astragalus confirmed the separation observed in PCA (fig. 7, table 4). The remains from LVF and CD were clearly separated from those from the other sites. Only one of the 57 specimens $(1.7 \%)$ overlapps $H$. matthewi from VM, $\mathrm{KS}, \mathrm{ML}$, and PAV. In the DA for the calcaneus, the remains from LVF and CD were also clearly separated from the rest. This group was well classified in $100 \%$ of cases (fig. 7, table 4). The DA for $1 \mathrm{PhIII}$ reproduced these results, but some specimens from LVF and CD overlapps the distribution of the HO specimens (fig. 6, table 4). The remains were well classified in $91.1 \%$ of cases, with one of 51 specimens $(1.8 \%)$ overlapping with those of $\mathrm{RO} 2$ and PM, another $(1.8 \%)$ with $H$. matthewi from VM, $\mathrm{KS}, \mathrm{ML}$, and PAV, and three more (5.4\%) with $H$. primigenium from $\mathrm{HO}$. These results indicate a strong similarity between the LVF and CD forms (table 4).

\section{Discussion}

The present results show that the remains of Hipparion from LVF and CD have similarities that clearly differentiate them from the materials from the other studied sites. Morphological affinities between them were confirmed in the bivariate and multivariate analyses, although some differences in dental and postcranial morphology were apparent. The hypsodonty index of the LVF specimens is lower than that of the CD specimens, and the occlusal morphology of the lower cheek teeth is more complicated in the LVF specimens (fig.8, table 1). These characters, hypsodonty and plication, would be related to different paleoenvironment conditions and consequently to the diet. The higher hipsodonty and the more complicated enamel plication are related with the drier conditions of the LVF environment. With respect to the postcranial skeleton, the metapods of both forms are slender, although the gracility index indicates the LVF specimens to be more slender than those from CD (the former are somewhat longer and the width of the diaphysis is smaller) (fig.8, table 2). These kinds the analyses confirmed the remains from LVF and $\mathrm{CD}$ to be very similar. Only a few morphological differences exist in the postcranial bones, PCA analysis showed them to overlap, and they merged in the DA analysis. The LVF and CD forms are clearly distinguished from the large forms from $\mathrm{HO}$, $\mathrm{PM}$, and RO2. The gracility indices also show that the LVF postcranial skeletons more closely resemble those from $\mathrm{CD}$ than those of $H$. primigenium from $\mathrm{HO}$ (table 2), although the MtIII, astragalus, calcaneus, and 1PhIII from LVF are more slender than the homologous bones from CD. Nonetheless, the body masses of the LVF and CD Hipparion taxa are similar (table 2). It is important to note the differences between the LVF and CD taxa and other Spanish Hipparion (Ortiz Jaureguizar \& Alberdi, 2003). The mean body mass of Hipparion from LVF was $170 \mathrm{~kg}$ with $1 \mathrm{PhIII} 5$, and $186 \mathrm{~kg}$ with McIII13. This is close to the mean weight of $160 \mathrm{~kg}$ with 1 PhIII5 and $178 \mathrm{~kg}$ with McIII13 for the CD form (table 2). These similarities in weight, morphological features, and the results of the bivariate and multivariate analyses suggest, as Forsten pointed out (1982) that the Hipparion from LVF and CD should be included within Hipparion concudense, although as belonging to different subspecies. In accordance with the priority rules (ICZN, 2000) the name of Hipparion concudense is prioritary. Thus, the taxonomical separation between $H$. c. melendezi, from the Duero Basin, and H. c. concudense, from the Calatayud-Teruel Basin, would be consequence of different environmental conditions between both Basins, an idea supported by the presence in LVF of a faunal assemblage which suggests drier environment than that from CD.

\section{Conclusions}

The present results show the similarities between $H$. concudense from Concud and H. p. melendezi from LVF, to be sufficient to assign them to the same species, $H$. concudense, agreeing with previous Forsten's (1982) proposal. However, these taxa are different enough to represent two subspecies: $H$. concudense melendezi Alberdi, 1974, and H. concudense concudense Pirlot, 1956, by the morphological and biometrical differences.

The dental morphology of $H$. concudense melendezi is somewhat more complicated, and the distal parts of its limbs (McIII, MtIII, AST, CAL, and 1PHIII) are more slender than those of H. concudense concudense.

\section{ACKNOWLEDGEMENTS}

We thank E. Cerdeño and G. Koufos for their critical reviews of this manuscript and valuable comments. The authors express their thanks to the Curators of the Museo Nacional de Ciencias 

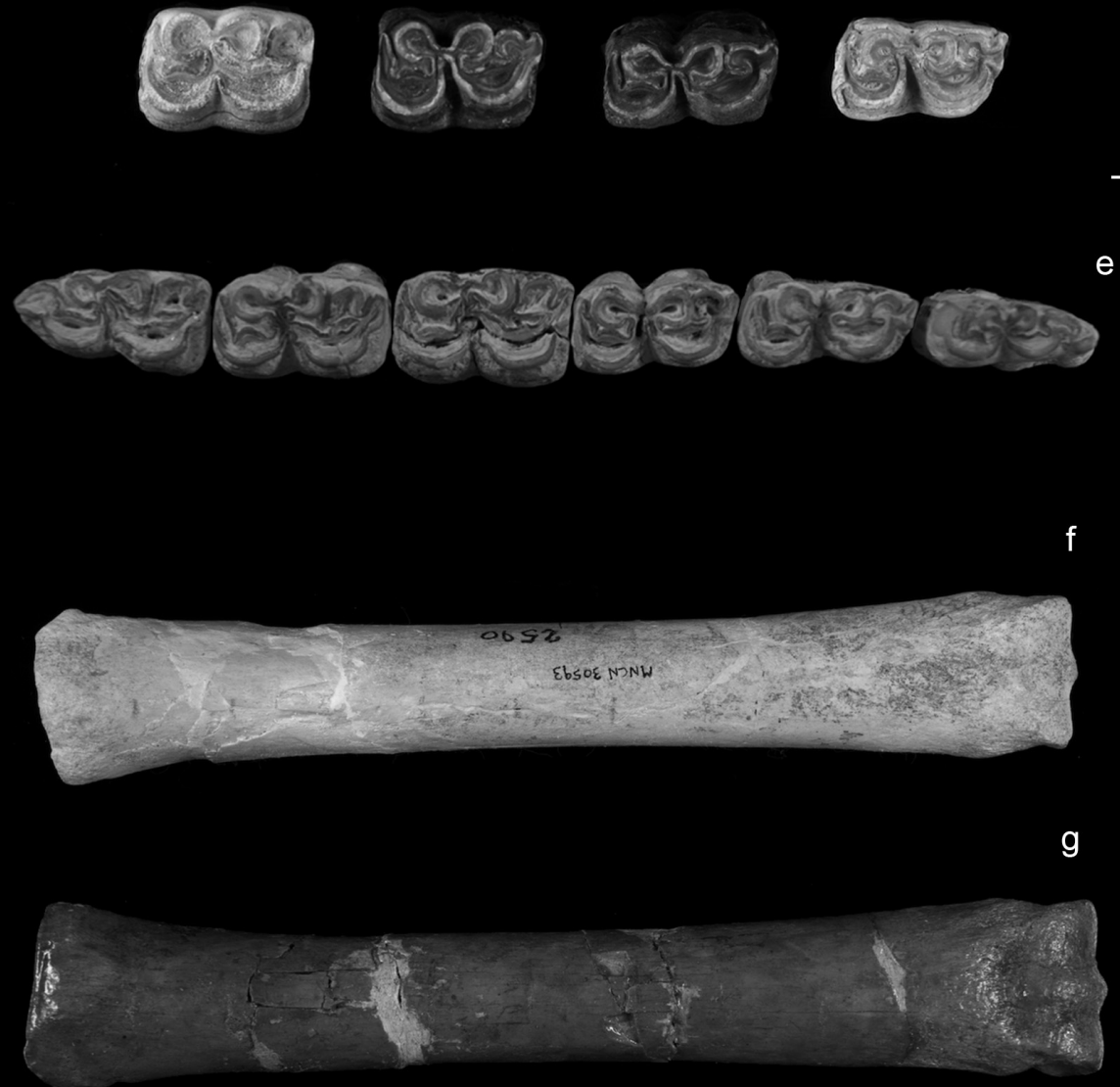

$1 \mathrm{~cm}$
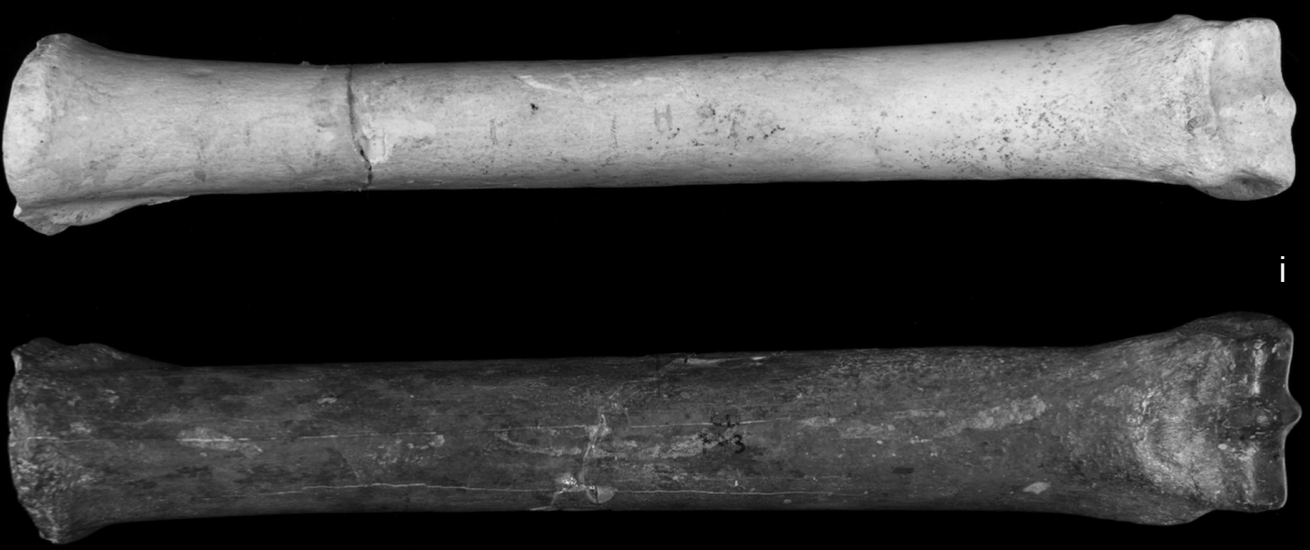

Figure 8.-Hipparion concudense concudense from Concud (Teruel, Spain) vs. Hipparion concudense melendezi from Los Valles de Fuentidueña (Segovia, Spain). a) MNCN-17685, right p3-4 from CD. b) MNCN-17679, right p3-4 from CD. c) MNCN-17765, right m12 from CD. d) MNCN-17753, m1-2 from CD. e) MNCN-30152, MNCN-30212, MNCN-30226, MNCN-30196, MNCN-30206, right lower series p2-m3 from LVF. f) MNCN-30593, left Mclll from LVF. g) MNCN-17204, right Mclll from CD. h) MNCN-30654, right MtIII from LVF. i) MNCN-17150, left MtIII from CD. 
Naturales, CSIC, Madrid. Adrian Burton revised the English text. This work was possible thanks to funding via the DGICYT Research Project CGL2007-60790/BTE.

\section{References}

Alberdi, M.T. (1974). El género Hipparion en España. Nuevas formas de Castilla y Andalucía, revisión e historia evolutiva. Trabajos Neógeno Cuaternario, 1: 1146.

Alberdi, M.T. (1989). A review of Old World Hipparionine Horses. In: The evolution of Perissodactyla (Prothero, D.R. \& Schoch, R.M., eds.). Oxford University Press, New York and Oxford, 234-261.

Alberdi, M.T.; López, N.; Morales, J.; Sesé, C. \& Soria, D. (1981). Biostratigrafía y biogeografía de la fauna de mamíferos de Los Valles de Fuentidueña (Segovia). Estudios Geológicos, 37: 503-511.

Alberdi, M.T.; Prado, J.L. \& Ortiz-Jaureguizar, E. (1995). Patterns of body mass changes in fossil and living Equini (Perissodactyla). Biological Journal of Linnean Society, 54: 349-370.

Alcala, L. (1994). Macromamíferos neógenos de la fosa de Alfambra-Teruel. Instituto de Estudios Turolenses y Museo Nacional de Ciencias Naturales, CSIC, Teruel, $554 \mathrm{pp}$.

Alcalá, L. (1998). Evaluación patrimonial de los yacimientos de vertebrados miocenos de Concud (Teruel). Comunicaciones IV Reunión Nacional Comisión Patrimonio Geológico, Sociedad Geológica de España, 29-32.

Alcalá, L.; Azanza, B.; Sánchez, B. \& Pesquero, M.D. (1999). The mammal sites from the Latest Miocene of Concud (Teruel). In: The Geological and Paleontological Heritage of Central and Eastern Iberia (Iberian Range, Spain) (Meléndez, G. \& Soria-Llop, C., eds.). Publicaciones Seminario Paleontología Zaragoza, 117-132.

Almela, A.; Bataller, J.R. \& Sampelayo, P.H. (1944). Un nuevo yacimiento de Vertebrados fósiles miocenos (con una nota paleontológica). Noticias de la Comisión del Instituto Geológico y Minero de España, 13: 1-10.

Bernor, R.L.; Tobien, H. \& Woodburne, M.O. (1990). Patterns of Old World Hipparionine evolutionary diversification and biogeographic extension. In: European Neogene Mammal Chronology (Londsay, E.H.; Fahlbusch, V. \& Mein, P., eds.). Plenum Press, New York, 263-319.

Bernor, R.L.; Koufos, G.D.; Woodburne, M.O. \& Fortelius, M. (1996). The Evolutionary History and Biochronology of European and Southwest Asian Late Miocene and Pliocene Hipparionine Horses. In: The Evolution of Western Eurasian Neogene Mammal Faunas (Bernor, R.L.; Falbusch, V. \& Mittmann, H.W., eds.). Columbia University Press, New York, 137-154.

Bernor, R.L.; Tobien, H.; Hayek, L.C. \& Mittmann, H.W. (1997). Hippotherium primigenium (Equidae, Mammalia) from the late Miocene of Höwenegg (Hegau, Germany). Andrias, 10: 1-230.
Bonadonna, F.P. \& Alberdi, M.T. (1987). The N/Q Boundary at 1.64 Ma?. Mediterránea, Serie geológica, 6: 115-130.

Christol, J. de (1832). Description of Hipparion (not title). Annales Science l'Industrie du midi de la France, 1: 180-181.

Cortázar, D. (1885). Bosquejo físico-geológico y minero de la provincial de Teruel. Boletín de la Comisión del Mapa Geoógico de España, 12: 263-607.

Crusafont, M. (1952). Los jiráfidos fósiles de España. Memorias de la Comisión del Instituto Geológico de la Diputación de Barcelona, 8: 1-239.

Crusafont, M. \& Truyols, J. (1954). Catálogo Paleomastológico del Mioceno del Vallés-Penedés y de Calatayud-Teruel. Sección Paleontológica Museo Sabadell.

Crusafont, M.; Aguirre, E. \& García, J. (1968). Un nuevo yacimiento de mamíferos del Mioceno superior de la cuenca del Duero. Acta Geológica Hispánica, 3: 22-24.

Eisenmann, V. (1995). What metapodial morphometry has to say about some Miocene Hipparions. In: Paleoclimate and Evolution, with Emphasis on Human Origins (Vrba, E.S.; Denton, G.H.; Partridge, T.C. \& Burckle, L.H., eds.). Yale University Press, New Haven and London, 148-163.

Eisenmann, V.; Alberdi, M.T.; De Giuli, C. \& Staesche, U. (1988). Collected papers after the «New York International Hipparion Conference, 1981». In: Studying fossil Horses, 1, Methodology (Woodburne, M. \& Sondaar, P., eds.). E.J. Brill, Leiden, 1-77.

Ezquerra del Bayo, J. (1850). Ensayo de una descripción general de la estructura geológica del terreno de España en la Península: sección $3^{\mathrm{a}}$. Memorias de la Academia de Ciencias de Madrid, Tomo 1: 161-184.

Forsten, A. 1968. Revision of the Palearctic Hipparion. Acta Zoologica Fennica, 119: 1-131.

Forsten, A. 1982. Hipparion primigenium melendezi Alberdi reconsidered. Annales Fennici Zoologici, 19: 109-113.

Gervais, P. (1852). Description des ossements fósiles de mammifères rapportés d'Espagne par MM. De Verneuil, Collomb et de Lorière. Bulletin de la Societe Geoogique de France, 10, 2a: 147-162.

Gray, H. (1821). On the natural arrangement of vertebrate animals. London Medical Repository Review, 15: 296-310.

Hernández-Pacheco, E. (1914). Los vertebrados terrestres del Mioceno de la Península Ibérica. Boletín de la Real Sociedad de Historia Natural, 9: 443-485.

Hoyos, M.; García del Cura, M.A. \& Ordóñez, S. (1981). Características geológicas del yacimiento de Los Valles de Fuentidueñas (Segovia). Estudios Geológi$\cos , 37$ : 345-351.

Meléndez, B.; Crusafont, M. \& Villalta J.F. (1944). Nuevo yacimiento Pontiense en la provincia de Segovia. Boletín de la Real Sociedad de Historia Natural, 42: 621-626.

Orlov, J.A. (1936). Fundort der "Hipparion" fauna am Irtysch in der Stadt Pavlodar (W. Siberien). Trudy Institut of Paleozoology, Academy of Sciences, 5: 155-59. 
Ortiz-Jaureguizar, E. \& Alberdi, M.T. (2003). El patrón de cambios en la masa corporal de los Hipparionini (Perissodactyla, Equidae) de la península ibérica durante el Mioceno superior - Plioceno superior. Coloquios de Paleontología, Vol. Ext. 1: 499-509.

Owen, R. (1848). Description of the teeth and portions of jaws of two extinct anthracotheroid quadrupeds discovered by the Marchioness of Hastings in the Eocene deposits of the N.W. coast of the Isle of Wight: With an attempt to develop Cuvier's idea of the classification of Pachyderms by the number of their toes. Quarterly Journal Geological Society of London, 4: 103141. doi:10.1144/GSL.JGS.1848.004.01-02.21

Pesquero, M.D. 2003. Hipparion del Turoliense superior de Las Casiones (Fosa de Teruel). Coloquios de Paleontología, Vol. Ext. 1: 511-548.

Pesquero, M.D.; Alberdi, M.T. \& Alcalá, L. (2006). The late Vallesian Hipparion from La Roma 2, Teruel, Spain: a study of the morphology and biometry variability of Hipparion primigenium. Journal of Paleontology, 80: 343-356. doi:10.1666/00223360(2006)080[0343:NSOHFL]2.0.CO;2

Pesquero, M.D.; Alberdi, M.T. \& Montoya, P. (2007). Hipparion (Equidae, Mammalia) from Venta del Moro (Valencia Province, Spain). Neues Jahrbuch für Geologie und Paläontologie Abhandlungen, 243: 273-297. doi:10.1127/0077-7749/2007/0243-0273

Pesquero, M.D.; Ascaso, C.; Alcalá, L. \& FernándezJalvo, Y. (2010). A new taphonomic bioerosion in a Miocene lakeshore environment. Palaeogeography,
Palaeoclimatology, Palaeoecology, 295: 192-198. doi:10.1016/j.palaeo.2010.05.037

Pesquero, M.D.; Alberdi, M.T. \& Alcalá, L. (2011). Remains of Hipparion (Equidae, Perissodactyla) from Puente Minero (Teruel Province, Spain) and their implications for the systematics of the Turolian Hipparionini. Palaeontology, 54 (6): 1303-1321.

Pirlot, P.L. (1956). Les formes européennes du genre Hipparion. Memorias de la Comisión Instituto de Geología, Diputación de la provincia de Barcelona, 14: 11-21.

Qiu, Z.; Huang, W. \& Guo, Z. (1987). The chinese Hipparionine fossils. Acta Paleontologica Sinica, 175: 196-250.

Royo Gómez, J. (1926). Tectónica del terciario Continental Ibérico. Boletín Instituto Geológico de España, 7: 131-168.

Sondaar, P.Y. (1961). Les Hipparion de l'Aragon meridional. Estudios Geológicos, 17: 209-305.

Villalta, J.F. \& Crusafont, M. (1947-1948). Les gisements de Mammifères du Néogène espagnol. VI. Bassin de Calatayud-Teruel. VII. Bassin du Tage. Comptes Rendus Société Géologique de France, 13-14: 278-280.

Wood II, H.E. (1937). Perissodactyl suborders. Journal of Mammalogy, 18:106.

Woodward, A.S. (1903). The Lower Pliocene Bone-bed of Concud, Province of Teruel, Spain. Geological Magazine, 10: 203-207. doi:10.1017/S0016756800112415

Recibido el 17 de noviembre de 2010 Aceptado el 21 de junio de 2011 Publicado online el 16 de enero de 2012 